\title{
RELIĢISKIE ASPEKTI VIDEOSPĒLĒS, GRAFISKAJĀS NOVELĒS UN KOMIKSOS
}

\section{Diāna Lozko}

Mg. theol.

Videospēḷu, komiksu un grafisko noveļu industrijas izmanto religiskos motīvus, tēlus un idejas, kuras nereti savijas arī dažādos eklektiskos veidojumos. Šo industriju motivācija ir dažāda - daḷa videospēḷu izstrādātāju ir izvēlējušies spēlēs atspogulıot reliǵiskos motīvos, koncentrējoties uz atbilstošu mērķauditoriju. Tā, piemēram, kristietība Rietumu pasaule ir viena no populārākajām relig̣ijām, tāpēc arī ir iespējams pieprasījums pēc šādas preces. Tieši šì iemesla dēḷ varam atrast arī dažādas specifiskas, piemēram, kristiešu, videospēles vai komiksus. Par piemēru varam ņemt videospēḷu sēriju Bible Adventure (1991), kurā spēles ar nosaukumu "Noasa šksirsts" (Noah’s Ark) veidotāji par galveno varoni ir izvēlējušies Noasu, kurš skraida pa mežu un k̦er dzīvniekus, kurus viņš nes uz savu milzīgo šksirstu. Savukārt nesen izstrādātā spēle "Apustuḷa Pāvila misija” (The Mission of Paul the Apostle) seko līdzi Pāvila cel̦am uz Damasku. Šajā spēlē ir l̦oti daudz Bībeles citātu. Tiesa, spēle neiztiek arī bez klasiskiem videospēles paņēmieniem - Pāvilam ir jācīnās ar sikspārņiem. Ja viņš tos nevar uzveikt paša spēkiem, spēlē var piesaukt Dieva izpalīdzīgo roku, kas sakauj visus sikspārņus. Spēles izstrādātājs Levijs Hiltons (Levi Hilton) uzsver, ka šì ir izglītojoša spēle, kura māca par Bībeli un kura radīta tādēḷ, lai bērni varētu aizraujošā un jautrā veidā apgūt zināšanas par Bībeli. ${ }^{1}$

Levi Hilton, "The Mission of Paul the Apostle: A Bible Video Game”, https:// www.kickstarter.com/projects/128714926/the-mission-of-paul-the-apostle-a-bible-video-game (skatīts 18.01.2018.) 
Citi videospēḷu, komiksu un grafisko novel̦u veidotāji savos darbos sajauc kopā dažādas reliǵiskās, filozofiskās un mistiskās idejas, kā arī veido eklektiskus tēlus un pat jaunas religijas. Nereti pazīstamas religisisko tēlu vai ideju konstrukcijas videospēḷu un komiksu veidotāji izmanto tādēḷ, ka šie tēli un idejas jau ir zināmi, līdz ar to spēlēm, komiksiem vai grafiskajām novelēm tiek nodrošināta lielāka atpazīstamība nekā gadījumā, ja tiktu veidoti pavisam jauni tēli.

Trešā kategorija ir tā, kurā visvairāk tiek apspēlēts garīguma jēdziens, piemēram, 2012. gada spēle "Ceḷojums" (Journey). Tās radošais direktors Jenova Čens (Jenova Chen) uzsver, ka spēles pamatā ir Džozefa Kempbela (Joseph John Campbell) grāmata "Varonis ar tūkstoš sejām" (The Hero with a Thousand Faces), un ikviens šajā spēlē var atpazìt klasiskos varoņus, kā arī pats sevi varoņa cel̦ojumā. ${ }^{2}$ Neiztrūkstoša ir arī "satīriskā" videospēḷu, komiksu un grafisko novel̦u kategorija, kurā pasmejas par dažādām reliğiskajām idejām un ar relig̣iju saistītajiem tēliem, kā, piemēram, spēle "Dievu cīņa" (Fight of Gods). Spēlē savā starpā divcīñā var cīnīties Jēzus ar Budu vai kādu citu dievību, kā arī ar kādu no mitoloǵiskajiem tēliem. Spēle ir bez šksietami padziḷināta satura un drīzāk vienkārši jautra, taču tajā, protams, var aizstāvēt kādu no savām pārliecībām.

\section{Relig̣ija populārajā kultūrā}

Itakas koledžas (ASV) Relig̣iju un filozofijas departamenta asociētās profesores Reičelas Vāgneres (Rachel Wagner) vārdiem, videospēles piedāvā sava veida kārtību šajā haotiskajā mūsdienu pasaulē, un tieši tādēḷ tās ir tik populāras. ${ }^{3}$ Savukārt asociētais profesors Vits Šislers (Vit Šisler, Kārḷa Universitātes Jauno mediju institūts, Prāga) uzsver, ka līdz ar 2000. gadu relig̣ijas pētniecības nozare aizvien vairāk pievērsusies tieši videospēḷu pētniecībai. ${ }^{4}$ Videospēles ar reliğisku kontekstu

2 Oficiālā videospēles Journey mājaslapa, https://www.playstation.com/enus/games/journey-ps4/ (skatits 26.01.2018.)

3 Rachel Wagner, "Video Games and Religion", http://www.oxfordhandbooks.com/view/10.1093/oxfordhb/9780199935420.001.0001/oxfordhb-9780199935420-e-8 (skatīts 23.01.2018.)

${ }_{4}$ Vít Šisler, Kerstin Radde-Antweiler, Xenia Zeiler, Methods for Studying Video Games and Religion (New York: Routledge, 2017), n. p. 
parādās tirgū, un tās iespaidojas no dažādām religisiskajām tradīcijām, kā arī ir gan izglītojošas, gan veicina starpkulturālu dialogu, tāpēc videospēles var gan reflektēt, gan noraidīt, kā arī rekonfigurēt reliǵiskās idejas. ${ }^{5}$

Religijas katedras doktors un pasniedzējs Konrāds Otsvalts (Conrad Otswalt) no Apalaču Valsts universitātes (Appalachian State University, ASV) postulē modeli, kādā veidā relig̣ija mijiedarbojas ar populāro kultūru. Viņaprāt, tās nav divas atdalāmas vienības un katra no tām atrod jēgu attiecībā pret otru. Viņš uzsver, ka relig̣ija ir kultūras forma, kas ir virzìta uz svēto un garīgo, un ka tā eksistē dialektiskās attiecībās ar citām kultūras formām, kuras dažbrīd skar religisisko kontekstu. K. Otsvalts apgalvo, ka religijia ir saistīta ar sekulāro kultūru un to nevar nošķirt no citām kultūras formām, kā arī tā nepastāv pilnībā ārpus kultūras konteksta. ${ }^{6} \mathrm{Li} d z$ ar to arī popkultūras elementu - komiksu un videospēlu - pētniecība teologijas nozares paspārnē ir nepieciešama un gluži vai neizbēgama.

\section{Supervaroṇu teoloğija}

Vairākiem komiksu varoņiem ir kāda religiska konteksta izcelsme. Ārons Dāvids Lūiss (Aaron David Lewis), pats būdams komiksu autors, kā arī relig̣iju un literatūras pētnieks, sarakstījis grāmatu "Izgrebtais attēls: religijija komiksos un grafiskajās novelēs" (Graven Images: Religion in Comic Books and Graphic Novels), kurā uzsvēris religijas tēmas nozīmi komiksu izveidē. Viñš akcentē, ka populāro kultūru saista dažādu reliğisko tēlu un kontekstu izmantošana. Daži eksperti uzskata, ka šāds reliǵiskais konteksts attiecībā uz supervaroņiem nereti vērojams tieši ASV, kur supervaronis ir patriotisma, religisisku simbolu un ideju savirknējums. ${ }^{7}$ Supervaronim ir jābūt kādas cilvēku grupas varonim, tāpēc viņš nereti aizgūst

${ }_{5} \quad$ Vít Šisler, Kerstin Radde-Antweiler, Xenia Zeiler, Methods for Studying Video Games and Religion (New York: Routledge, 2017), n. p.

${ }_{6}$ Conrad Otswalt, "Secular Steeples: Popular Culture and the Religious Imagination," in Understanding Religion and Popular Culture, Terry Ray Clark, Dan W. Clanton Jr. (New York: Routledge, 2012), 8.

7 N. a., "Superheroes and spirituality: The religion of the comic book," http://www.religionlink.com/source-guides/superheroes-and-spirituality-the-religion-of-the-comic-book/ (skatits 18.01.2018.) 
savas rašanās vides ideologiju, atpazīstamo kontekstu un cēlos ideālus. Labs piemērs tam ir Latvijā izdotā Kao Vieta Ngujena (CaoViet Nguyen) grafiskā novele "Lāčplēša hronika" (2012). Pirmajā šīs grafiskās noveles lapaspusē attēlota Dievu sapulce, kurā norit Kārtas un Dēklas saruna par to, ka nav iespējams mainīt Lāčplēša likteni, lai cik tas arī rādās grūts. Turpmāk grafiskā novele attēlo gan Svētā Pērkona vecāko dēlu Zibeni, gan jūras dievu Antripu, kā arī vel̦u valstību, Ūsiņu, Pērkontēvu, Laimu un pašu Likteņtēvu. Daudziem cilvēkiem Latvijas kontekstā ir saprotami šie tēli, viņu nestās idejas, un to ir svarīgi apzināties, pētot katra attiecīgā komiksa un grafiskās noveles izcelsmes vietu, tur valdošos uzskatus un idejas.

Tēli nereti iegūst sev pazīstamas vides kontekstu, taču notiek arī dažādu reliğisko kontekstu saplūšana un to robežu sajaukšana. Tas uzskatāmi redzams komiksos un grafiskajās novelēs, kurās tēliem ir dažādu religisisko tradīciju konteksts, tādējādi komiksu tēls kḷūst atpazīstamāks aizvien vairākiem reliğiskajiem kontekstiem. Šāds paņēmiens, kā jau minēts iepriekš, var tikt izmantots, lai grafiskā novele gūtu lielāku popularitāti, kā arī lai attiecīgo tēlu padarītu vēl interesantāku, gluži vai piesātinātu ar reliǵiskām idejām, misticismu un filozofiskām atziñām. Protams, ir arī piemēri, kad grafisko noveļu un komiksu autori relig̣isko kontekstu izmanto kā satīru un retos gadījumos arī kā kādas reliǵiskās tradīcijas aizskarošu pañēmienu.

Komiksi un grafiskās noveles ir platforma, kurā religijijas kontekstu var gan aplūkot virspusēji, gan arī iedzilıināties tajā, tādējādi paverot plašas diskusijas iespējas. Tieši šie piemēri liek apzināties, ka komiksi un grafiskās noveles būtu jāņem vērā daudz nopietnāk, nekā tas sākumā varētu šksist. Nemanot tieši šis medijs var ienest aizvien svarīgākus un vienmēr aktuālus jautājumus sabiedrībā. Tā, piemēram, grāmatas "Karš, politika un supervaroñi: ètika un propaganda komiksos un filmās" (War, Politics and Superheroes: Ethics and Propaganda in Comics and Film) autors Marks Dipaolo (Marc DiPaolo) uzsver, ka gan kādreizējais ASV prezidents Baraks Obama (Barack Obama), gan amerikāņu žurnāliste, feministe un politiskā aktīviste Glorija Steinema (Gloria Steinem), kā arī literatūras profesors Edvards Saīds (Edward Said) ir publiski atzinuši, ka tādi supervaroņi kā Brīnumsieviete (Wonder Woman) un 
Zirnekḷcilvēks (Spider man) ir viņus iedvesmojuši. ${ }^{8}$ Komiksu un grafisko novel̦u autors Marks Millars (Mark Millar) novērojis, ka visaktuālākie komiksu un grafisko novel̦u tēli un stāsti kḷūst tieši dažādu nemieru un sarežğìtu politisko situāciju laikā, tādējādi norādot uz to, ka tie atspoguḷo apkārt notiekošo. ${ }^{9}$ Šajā laikmetā publisko domu visvairāk var ietekmēt tieši stāsti par supervaroniem, kuri ir daudz nopietnāka platforma, nekā tas sākumā varētu šķist. ${ }^{10}$ Taisni tādā pašā veidā komiksu un grafisko novel̦u platforma ir milzīgs un nozīmīgs lauks, kurā var notikt un notiek religiskais dialogs.

Kā min Leks Lutors (Lex Luthor) 1978. gada filmā "Supermens: filma" (Superman: The Movie), daži cilvēki var izlasīt grāmatu "Karš un miers" un uztvert to kā vienkāršu piedzīvojumu stāstu, bet citi var izlasīt izejvielu sastāvu uz košlājamās gumijas iepakojuma un atminēt visa universa noslēpumus. ${ }^{11}$

Tā arī teologijas laukā nevajadzētu atstāt novārtā populārās kultūras fenomenu pētniecību. Šajā jomā ir nepieciešama padziļinātāka pētniecība un nevajadzētu šos medijus un to pētniekus atstāt bez iespējas diskutēt un radìt aizvien jaunu religisko diskursu.

\section{Religijijas attēlojums videospēlēs}

Grāmatas "Dievs mašīnā: videospēles kā tiekšanās pēc garīguma" (God in the Machine: Video Games as Spiritual Pursuit) autors Liels Leibovics (Liel Leibovitz) uzdod retoriskus jautājumus par to, ko gan Heidegers teiktu par videospēli "Halo" vai ko svētais Augustīns teiktu par spēli Assasin's Creed. Var jau būt, ka lielie filozofi un teologi neskartu tik nenozīmīgu tēmu kā videospēles, taču L. Leibovics uzsver, ka videospēles kḷūst par vienu no noteicošajiem mūsdienu aspektiem. Tieši dažādo aizspriedumu dēḷ videospēḷu lauks vēl aizvien netiek pietiekami pētīts, taču tas ir jādara. Videospēles ir daḷa no populārās

s Marc DiPaolo, War, Politics and Superheroes: Ethics and Propaganda in Comics and Film (North Carolina: McFarland, 2011), 1.

9 Mark Millar "Wanted," in War, Politics and Superheroes: Ethics and Propaganda in Comics and Film, Marc DiPaolo (North Carolina: McFarland, 2011), 1.

10 Ibid.

11 Richard Donner, Superman: The Movie (Warner Bros. Entertainment Inc., 1978). 
kultūras, taču tās cilvēku ietekmē daudz citādāk nekā televīzija, drukāta prese vai interneta vidē pieejamais saturs. Videospēḷu spēlēšanā iesaistās cilvēka maņas, un piedāvāto informāciju viņš uztver tādā veidā, kurā viņš var iesaistīties pilnībā. ${ }^{12}$ Tā, piemēram, jau darba sākumā minēto spēli Journey cilvēki mēdz uztvert dažādi. Kādam tā ir garlaicīga skraidīšana ar varoni pa dīvainu pasauli, bet kādam citam š̄̄ spēle nozīmē l̦oti daudz un sniedz tādu pašu garīguma izjūtu un pieredzi, kā to darītu kādi svētie raksti vai atrašanās kādā no relig̣iskajām svētvietām, dievkalpojumiem vai meditācijā. Tā, piemēram, oficiālajā spēles mājaslapā kāda no spēlētājām teic, ka tieši šì spēle ir bijusi viņas dziedināšanas pamatnosacījums - iešana kaut kam cauri. Kādam citam spēlētājam šī spēle palīdzējusi atskārst, ka viñam nav jāizdzìvo savas bēdas vai iekšējie celsojumi vienatnē. ${ }^{13}$ Šis fenomens atklāj ko būtisku - videospēḷu spēju vienot cilvēkus, kā arī piedāvāt tiem jebko, kas tiem ir nepieciešams, - ideolog̣iju, antiideolog̣iju, vienkāršu izklaidi vai arī garīgu pārdzīvojumu.

Kā min R. Vāgnere, videospēles sniedz sava veida kārtību šajā haotiskajā pasaulē un gluži kā Dž. Kempbela varoņa ceḷojumā ikvienam cilvēkam reizumis jānokḷūst tumšākajā alā. Videospēles palīdz šādu cīṇu pārdzīvot uz ekrāna un ar videospēles varoņu palīdzību izspēlēt arī savas dzīves nozīmīgākās cīņas, šajās cīņās ietilpst arī garīgie pārdzīvojumi. Kā savā grāmatā "Ceḷi uz svētlaimi: mitologija un personīgā transformācija" (Pathways to Bliss: Mythology and Personal Transformation) min Dž. Kempbels, cilvēku jaunībā sagaida vilšanās, kad viņš vairs nevar paḷauties tikai uz tēvu un māti, bet viņam pašam jākḷūst par tēvu vai māti un jāuzņemas rūpes un atbildība. Tikai stājoties pretī dzīves izaicinājumiem, cilvēks var kḷūt pieaudzis. ${ }^{14}$ Dž. Kempbels uzsver: lai cilvēks kḷūtu pieaudzis, viņam ir jāiziet cauri šiem tumšajiem vārtiem, kuriem ir grūti iziet cauri, ja cilvēks uzskata, ka viņa ego ir

12 Liel Leibovitz, God in the Machine: Video Games as Spiritual Pursuit (New York: Templeton Press, 2015), 3.

13 Playstation oficiālā tīmekḷa vietne, https://www.playstation.com/en-us/ games/journey-ps4/ (skatīts 26.01.2018.)

${ }_{14}$ Joseph Campbell, Pathways to Bliss: Mythology and Personal Transformation (N. p.: RHYW, 2009), 116. 
viņš pats. ${ }^{15}$ Lìdz ar to arī videospēles palīdz iet cauri šiem vārtiem, kaut uz laiku radot cilvēkā alter ego, kurš uz to brīdi tad arī nes viņa ego patību, kamēr cilvēks pats var palikt novērotāja lomā.

\section{Nobeigums}

Komiksi, grafiskās noveles un videospēles populārajā kultūrā nereti nes daudz dziḷāku vēstījumu, nekā tas sākotnēji varētu šksist. Šie mediji atspoguḷo populāro kultūru, un tajos ir vērojamas religiskas atsauces. Tās ne vienmēr tiek izmantotas tikai jaunu skatītāju, spēlētāju un lasītāju piesaistei, bet sniedz arī padziḷinātāku iespēju relig̣isko tēmu diskursam. Dažādi autori reliğiskos motīvus un idejas savos darbos izmanto dažādu mērķu vadīti, taču nevaram noliegt, ka no tiem var iegūt dažāda spektra informāciju, kā arī pieredzi. Dažreiz kāda grafiskā novele, supervaroņa stāsts vai videospēle cilvēkam lauj piedzīvot visgarīgāko savas dzīves pieredzi un veikt pašam savu varoņa celsojumu.

Minētie mediji ir populārās kultūras un attiecīgā laika spogulis, kurā religisiskie tēli un idejas var ieņemt dažādas vietas. Būtībā aktuāls jautājums ir nevis par to, ka šie mediji ietekmē cilvēku, viņa garīgos meklējumus un religiskās atklāsmes, bet par to, kā tieši tas notiek un kādā veidā šis process var cilvēkus aizvest līdz daudz dziḷāku jautājumu atklāšanai. Tieši tādēl ieteicams veikt turpmākus pētījumus par popkultūras un reliğijas simbiozes jautājumiem un piemēriem, kā arī pētīt relig̣isko un garīguma konceptu esamību komiksos, grafiskajās novelēs un videospēlēs.

15 Joseph Campbell, Pathways to Bliss: Mythology and Personal Transformation (N. p.: RHYW, 2009), 116. 


\section{Summary}

Religious aspects in video games, graphic novels and comic strips

Religious aspects in video games, graphic novels and comic strips appear for a variety of reasons, and it cannot be denied that the study of this topic is important in theology. In the context of popular culture, it is necessary to study the aspects of religion as well as the symbiosis of contemporary cultural and religious ideas. If the research of pop culture elements is left aside, the field of theology loses a significant insight into these different phenomena and their impact on religious studies. 